\title{
Some technical modifications in oesophageal resection for carcinoma
}

\author{
S. J. STEPHEN and C. G. URAGODA \\ The General Hospital, Colombo and the Chest Clinic, Kandy, Ceylon
}

\begin{abstract}
The frequency of oesophageal carcinoma in Ceylon provides an opportunity for elaborating certain modifications in the technique of oesophageal resection. Initial subadventitial ligation of oesophageal branches of the aorta renders the operative field relatively bloodless, thus facilitating the removal en bloc of the tumour together with the lymphatic and loose cellular tissue, as well as the adventitia of the aorta when it is involved. The division of the oesophagus above the growth in an oblique plane, leaving a posterior flap, helps to minimize the incidence of fibrous strictures and anastomotic leaks. In fashioning the stomach tube, the stomach is divided just proximal to the beginning of the left gastro-epiploic arch. This procedure ensures that the blood supply to the gastric component of the oesophagogastric anastomosis is least disturbed. In cases where the transverse colon and hepatic flexure are used as an interposition, a dual blood supply derived from the middle colic as well as the ascending branch of the left colic artery is retained. This procedure increases the margin of safety in case one artery obstructs.
\end{abstract}

Oesophageal carcinoma is the commonest intrathoracic tumour admitted to thoracic units in Ceylon. The high frequency of the tumour is probably related to betel chewing (Stephen and Uragoda, 1970). On the other hand, bronchial carcinoma is infrequent in the country (Uragoda, 1967) and this could be explained on the basis of the low consumption of tobacco by smoking (Uragoda and Senewiratne, 1972). This situation is the reverse of the position that prevails in the United Kingdom. In 1968, a total of 403 patients were admitted to the thoracic unit at the General Hospital, Ratnapura, Ceylon and of them $68(16.8 \%)$ were for oesophageal carcinoma, while only three $(0.7 \%)$ had bronchial malignancy.

The problem of oesophageal carcinoma poses a formidable challenge to thoracic surgeons in Ceylon, as it remains one of the most difficult malignancies to treat surgically, though there has been an improvement in the results of surgery during the past few years (Nakayama, 1959; Dunlop, 1960 ; Miller, 1962). Among the factors contributing to this improved outlook is the better understanding of the problems concerning oesophageal anastomosis. Therefore the anastomotic technique adopted in the management of these patients is of considerable interest.

\section{MATERIAL}

A total of 323 patients with primary carcinoma of the oesophagus was treated in two thoracic units in Ceylon from October 1963 to June 1969. Surgical exploration was carried out in 171 of these patients. 응 Resection was performed in 155 (90.6\%). A tubex of stomach was used to bridge the gap in 1340 resections, colon in 20 , and in the remaining one Wookey plastic tube and skin graft were used.

RESECTABILITY The policy adopted in this serieso has been one of resection of the growth whenever this could be achieved, irrespective of whethero the tumour and regional lymph nodes could be removed completely or not.

Resection was considered curative in 1010 patients, while in 54 it was palliative as clearance of tumour tissue and lymph nodes was inade- quate. Table I shows the type of resection according to site. The latter was determined by dividing the oesophagus into three $8-\mathrm{cm}$ divisions accord -5 ing to the oesophagoscopic level starting from the pharyngo-oesophageal junction, which waso taken as $15 \mathrm{~cm}$ from the upper incisor teethष्ठ (Dunlop, 1961).

In 10 patients $(5.8 \%)$ even a palliative resection was not possible, and therefore a bypass anastomosis was carried out, while six cases $(3.5 \%) \hat{~}$ 
T A B L E I

TYPE OF RESECTION ACCORDING TO SITE

\begin{tabular}{|c|c|c|c|c|c|}
\hline \multirow[t]{2}{*}{ Site } & \multicolumn{2}{|c|}{$\begin{array}{l}\text { Curative } \\
\text { Resection }\end{array}$} & \multicolumn{2}{|c|}{$\begin{array}{l}\text { Palliative } \\
\text { Resection }\end{array}$} & \multirow[t]{2}{*}{ Total } \\
\hline & No. & $\%$ & No. & $\%$ & \\
\hline $\begin{array}{l}\text { Upper third } \\
\text { Middle third } \\
\text { Lower third }\end{array}$ & $\begin{array}{r}8 \\
45 \\
48\end{array}$ & $\begin{array}{l}72 \cdot 7 \\
57 \cdot 7 \\
72 \cdot 7\end{array}$ & $\begin{array}{r}3 \\
33 \\
18\end{array}$ & $\begin{array}{l}27 \cdot 3 \\
42 \cdot 3 \\
27 \cdot 3\end{array}$ & $\begin{array}{l}11 \\
78 \\
66\end{array}$ \\
\hline Total & 101 & $65 \cdot 2$ & 54 & $34 \cdot 8$ & 155 \\
\hline
\end{tabular}

were found to be unsuitable for even this procedure.

Of the 155 who underwent resection, 140 patients $(91.6 \%)$ had extra-oesophageal spread. Involvement of the paratracheal, subcarinal, and hilar lymph nodes was very common with growths of the middle third. Jeyasingham, Beligaswatte, and Sandrasegara (1967) found a similar situation in another Ceylon series, while such involvement is uncommon in the west.

The frequency of extra-oesophageal spread reflects the late stage of the disease when patients first reported for treatment.

In cases where aortic involvement had taken place, invasion beyond the adventitia was found to be uncommon. There were 30 patients with this complication, and in $24(80 \%)$ the infiltration was limited to this layer only, thus permitting its removal along with the growth.

The tumour could easily be separated from the air passages unless the latter were shown to be involved at bronchoscopy (Collis, 1965). In 17 patients it was fixed to the bronchus, and in 12 $(70.6 \%)$ it was freed without difficulty.

Mustard and Ibberson (1956) had a resectability rate of $75.2 \%$; in the present series it was $90.6 \%$ in the 171 patients explored. This high figure may be due partly to the resection of tumours adherent to the aorta and air passages.

OESOPHAgEAL ANASTOMOSIS The initial step in the operation is subadventitial ligation of the oesophageal branches of the aorta. This renders the operative field relatively bloodless, and the tumour with the lymphatic and loose cellular tissue, along with the adventitia of the aorta when it is involved, can then be removed en bloc.

In oesophageal resection the standard procedure has been for the oesophagus to be divided transversely proximal to the growth before its anastomosis with the stomach, colon or jejunum. A drawback of this method is the possible formation of annular anastomotic strictures. If the oesophagus is divided obliquely instead of transversely, such strictures can be avoided to a large extent for the suture line is then no longer annular. Another advantage of oblique division is that the oesophageal end can be trimmed to the diameter of stomach tube or colon, thus facilitating accurate mucosa to mucosa apposition.

The plane in which the oblique section is to be carried out has to be selected after considering the direction of the blood supply to the oesophagus so that there would be the least amount of interference to these vessels. Though subject to individual variation, the major arterial supply to the thoracic oesophagus generally enters it from a posterolateral aspect (Swigart, Siekert, Hambley, and Anson, 1950). Therefore oblique division of the oesophagus in such a way as to leave a posterior flap ensures that the arterial supply to this flap is maintained in a uniformly satisfactory manner.

Oesophageal anastomosis in the entire series was carried out by using two layers of interrupted No. 60 atraumatic linen thread with no mucosa projecting through the suture line. A nasal tube was used in all the cases, and this was removed after 12 to 24 hours.

Stomach tube A tube fashioned from stomach was used to bridge the gap in 134 resections. This method was adopted in lower and middle third growths except in cases where lymphatic spread along the right gastro-epiploic arch had made the stomach unsuitable for this procedure (Table II). The surgical approach was left-sided for lower third growths, while it was right-sided in 69 out of 78 middle third tumours.

Short gastric arteries do not anastomose outside the wall of the stomach with each other nor with other arteries to the stomach (Hollinshead,

T A B L E I I

OPERATIVE APPROACH IN 155 RESECTIONS

\begin{tabular}{|c|c|c|c|c|}
\hline Site & Operative Approach & Type of Graft & No. & Total \\
\hline $\begin{array}{l}\text { Upper } \\
\text { third }\end{array}$ & $\begin{array}{l}\text { Neck, right chest, and } \\
\text { abdomen } \\
\text { Pharyngolaryngectomy }\end{array}$ & $\begin{array}{l}\text { Colon } \\
\text { Wookey plastic } \\
\text { tube and skin } \\
\text { graft }\end{array}$ & $\begin{array}{r}10 \\
1\end{array}$ & 11 \\
\hline $\begin{array}{r}\text { Middle } \\
\text { third }\end{array}$ & $\begin{array}{l}\text { Abdominal and right } \\
\text { posterolateral } \\
\text { (Lewis) and } \\
\text { pyloroplasty } \\
\text { Left thoracotomy }\end{array}$ & $\begin{array}{l}\text { Stomach tube } \\
\text { Colon } \\
\text { Stomach tube }\end{array}$ & $\begin{array}{r}61 \\
8 \\
9 \\
\end{array}$ & 78 \\
\hline $\begin{array}{l}\text { Lower } \\
\text { third }\end{array}$ & $\begin{array}{l}\text { Left thoracotomy } \\
\text { Left abdominothoracic }\end{array}$ & $\begin{array}{l}\text { Stomach tube } \\
\text { Colon }\end{array}$ & $\begin{array}{r}64 \\
2 \\
\end{array}$ & 66 \\
\hline & & Total & & 155 \\
\hline
\end{tabular}


1956). In fashioning the stomach tube by excising the fundus and the lesser curvature, the fact that only the distal portion of the greater curvature is supplied by a continuous arcade is taken into consideration. The stomach is transected along a line just proximal to the commencement of the left gastro-epiploic arch, thus ensuring the maximum blood supply to the gastric component of the anastomotic line.

Colonic interposition Transverse colon and hepatic flexure were used as an interposition in 20 cases (Table II). This was done in upper third resections, as well as in the lower and middle third where the stomach was found to be unsuitable.

In the standard technique adopted for interposition of transverse colonic segment, the colonic graft was fed only by the middle colic artery (Nakayama, 1959; Blades and Winfrey, 1966). The technique used in this series was a modification whereby a dual blood supply from the middle colic artery as well as the ascending branch of the left colic was retained.

The right colic artery was divided at its origin, and the ascending colon was transected at the junction of the proximal two-thirds with the distal third. The proximal end of the colonic segment was drawn behind the stomach and anastomosed to the proximal oesophagus. The end arteries from the peripheral arterial arcade to the splenic flexure were divided between fine ligatures, preserving the continuity of the ascending branch of the left colic artery with the left branch of the middle colic artery. The colon was divided at the splenic flexure and its proximal end was drawn over the anterior surface of the stomach and anastomosed to it. In some instances about $5 \mathrm{~cm}$ of the splenic flexure had to be excised.

\section{RESULTS}

In this series of 155 resections, oblique division of the oesophagus was carried out in the last 80 cases, the other technical considerations remaining constant throughout. Sixteen patients $(76 \cdot 2 \%)$ among the 21 survivors of the first 75 resections, in whom the oesophageal division was done transversely, developed anastomotic strictures by the end of 18 months' follow-up. Biopsy of the stricture showed recurrence of the tumour in only two cases, it being fibrous in nature in the remaining 14. In the second group of 80 resections, anastomotic stricture occurred in only three $(10.7 \%)$ of
T A B L E I I I

OPERATIVE MORTALITY

\begin{tabular}{|c|c|c|c|c|c|c|}
\hline \multirow[b]{2}{*}{ Site } & \multicolumn{2}{|c|}{$\begin{array}{c}\text { First } 75 \\
\text { Resections }\end{array}$} & \multicolumn{2}{|c|}{$\begin{array}{l}\text { Latter } 80 \\
\text { Resections }\end{array}$} & \multicolumn{2}{|c|}{ Total } \\
\hline & $\begin{array}{l}\text { No. of } \\
\text { Resec- } \\
\text { tions }\end{array}$ & $\begin{array}{l}\text { Mort- } \\
\text { ality }\end{array}$ & $\begin{array}{c}\text { No. of } \\
\text { Resec- } \\
\text { tions }\end{array}$ & $\begin{array}{l}\text { Mort- } \\
\text { ality }\end{array}$ & No. & Mort:- \\
\hline Upper third & 5 & $\stackrel{2}{2}$ & 6 & $\stackrel{2}{2}$ & 11 & 4 \\
\hline Middle third & 30 & $7^{70}$ & 48 & $6^{\circ}$ & 78 & \\
\hline Lower third & 40 & $(15.0 \%)$ & 26 & $\begin{array}{c}(12.5 \%) \\
2 \% \\
(7 \cdot 7 \%)\end{array}$ & 66 & $(12.1 \%$ \\
\hline Total & 75 & $\begin{array}{c}15 \\
(20.0 \%)\end{array}$ & 80 & $\begin{array}{c}10 \\
(12 \cdot 5 \%\end{array}$ & 155 & (16.1 \\
\hline
\end{tabular}

T A B L E I V

CAUSE OF OPERATIVE DEATHS

\begin{tabular}{|c|c|c|c|c|}
\hline \multirow{2}{*}{ Cause } & \multicolumn{2}{|c|}{$\begin{array}{c}\text { Deaths in First } \\
75 \text { Cases }\end{array}$} & \multicolumn{2}{|c|}{$\begin{array}{c}\text { Deaths in Latte } \\
80 \text { Cases }\end{array}$} \\
\hline & No. & $\%$ & No. & $\%$ \\
\hline $\begin{array}{l}\text { Anastomotic leak } \\
\text { Cardiac failure } \\
\text { Pulmonary infection } \\
\text { Suxamethonium apnoea }\end{array}$ & $\begin{array}{l}7 \\
4 \\
3 \\
1\end{array}$ & $\begin{array}{r}46.6 \\
26.6 \\
20.0 \\
6.8\end{array}$ & $\begin{array}{l}2 \\
3 \\
3 \\
2\end{array}$ & $\begin{array}{l}20 \cdot 0 \\
30 \cdot 0 \\
30 \cdot 0 \\
20 \cdot 0 \leqq\end{array}$ \\
\hline Total & 15 & $100 \cdot 0$ & 10 & 100.0 \\
\hline
\end{tabular}

the 28 survivors after a similar period of followup.

Table III shows the operative mortality in the series, the overall figure being $16 \cdot 1 \%$ for the $1 \%$ resections. There was a significant reduction the mortality rate in the group of 80 cases where oblique division of the oesophagus was employed. The main contribution towards this lowering mortality came from the reduction of anastomote leaks from $46.6 \%$ to $20.0 \%$ (Table IV).

\section{DISCUSSION}

The mortality associated with the operative prê. cedure itself contributes to the poor outlook oesophageal cancer. Operative mortality figures differ from country to country and from centfe to centre. The surgical procedure adopted as well as the level of the tumour has an important bearing on these figures. Sweet (1954) reported ofa mortality of $24.3 \%$ for resection of middle thing tumours and $11.6 \%$ for lower third tumous. le Roux (1961), in a review of 418 oesophag 8 gastrectomies performed in a thoracic surgiel unit in Edinburgh, reports an overall mortalify of $30.0 \%$, anastomotic leaks contributing to onethird of the deaths. 
Any departure from the standard technical procedure that would help in lowering the operative mortality could be considered as a step in improving the prognosis. This series is characterized by modifications of surgical technique consisting of oblique division of the oesophagus above the tumour, retention of a dual blood supply to the interposed colonic segment, section of the stomach just proximal to the commencement of left gastroepiploic arch, and sub-adventitial ligation of oesophageal branches of the aorta. With the employment of these measures the overall operative mortality was kept down to $16 \cdot 1 \%$. Oblique division of the oesophagus appears to have made an important contribution to the improved results, for with its introduction the mortality dropped from $20.0 \%$ to $12.5 \%$, though it cannot be denied that at least a small measure of this improvement may have been due to the greater experience that attended the latter resections. The aim of the technique when it was first introduced was to reduce the incidence of annular anastomotic strictures. The results show that, in addition to achieving this end, it reduced the frequency of anastomotic leaks and thereby contributed to the reduction in the mortality rate.

One of the primary considerations in oesophageal surgery is the provision of an adequate blood supply to the anastomotic site of the gastric or colonic interposition. The retention of the ascending branch of the left colic artery helps to supplement the blood supply to the distal end of the colonic segment. Further, it serves as an alternative source of blood supply to the whole segment in case the flow through the middle colic artery is impaired due to thrombosis or kinking.

We wish to thank Mr. A. Vijeragavan, surgeon, General Hospital, Ratnapura, and Dr. (Mrs.) B. Stephen for their assistance.

\section{REFERENCES}

Blades, B., and Winfrey, E. W. (1966). In Surgical Diseases of the Chest, edited by B. Blades, 2nd ed., p. 277. C. V. Mosby, Saint Louis.

Collis, J. [L. (1965). In Clinical Surgery, vol. Thorax, edited by A. L. d'Abreu, p. 347. Butterworths, London.

Dunlop, E. E. (1960). Carcinoma of the oesophagus with survival. Aust. N.Z. J. Surg., 30, 81.

(1961). Carcinoma of the oesophagus. Ann. roy. Coll. Surg. Engl., 29, 28.

Hollinshead, W. H. (1956). Anatomy for Surgeons, vol. 2 The Thorax, Abdomen, and Pelvis, p. 394. HoeberHarper, New York.

Jeyasingham, K., Beligaswatte, A. M. L., and Sandrasegara, F. A. (1967). Carcinoma involving the oesophagus. Ceylon med.J., 12, 187.

le Roux, B. T. (1961). An analysis of 700 cases of carcinoma of the hypopharynx, the oesophagus, and the proximal stomach. Thorax, 16, 226.

Miller, C. (1962). Carcinoma of the thoracic oesophagus and cardia. Brit. J. Surg., 49, 507.

Mustard, R. A., and Ibberson, O. (1956). Carcinoma of the esophagus; a review of 381 cases admitted to Toronto General Hospital, 1937-1953 inclusive. Ann. Surg., 144, 927.

Nakayama, K. (1959). Statistical review of five-year survivals after surgery for carcinoma of the esophagus and cardiac portion of the stomach. Surgery, 45, 883.

Stephen, S. J., and Uragoda, C. G. (1970). Some observations on oesophageal carcinoma in Ceylon, including its relationship to betel chewing. Brit. J. Cancer, 24, 11 .

Sweet, R. H. (1954). Present status of the treatment of carcinoma of the esophagus. Arch. Surg., 69, 1.

Swigart, La V. L., Siekert, R. G., Hambley, W. C., and Anson, B. J. (1950). The esophageal arteries; an anatomic study of 150 specimens. Surg. Gynec. Obstet., 90, 234.

Uragoda, C. G. (1967). Incidence of bronchial carcinoma in a Ceylon chest clinic. Brit.J. Dis. Chest, 61, 154.

, and Senewiratne, B. (1972). Tobacco smoking in Ceylon. J. trop. Med. Hyg., in press. 